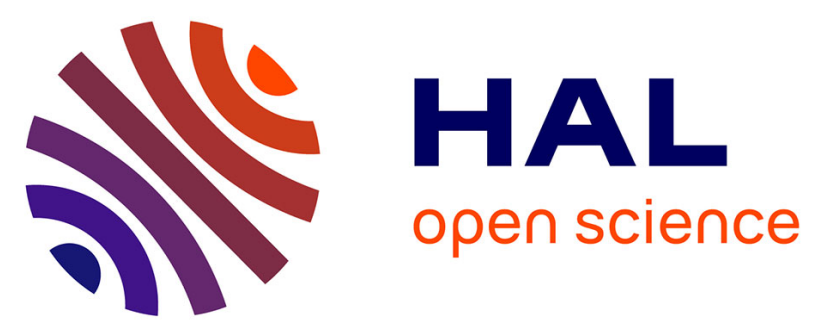

\title{
Reversible-Deactivation Radical Polymerization of Methyl Methacrylate and Styrene Mediated by Alkyl Dithiocarbamates and Copper Acetylacetonates
}

Yaozhong Zhang, Kristin Schröder, Yungwan Kwak, Pawel Krys, Aurélie Morin, Tomislav Pintauer, Rinaldo Poli, Krzysztof Matyjaszewski

\section{To cite this version:}

Yaozhong Zhang, Kristin Schröder, Yungwan Kwak, Pawel Krys, Aurélie Morin, et al.. ReversibleDeactivation Radical Polymerization of Methyl Methacrylate and Styrene Mediated by Alkyl Dithiocarbamates and Copper Acetylacetonates. Macromolecules, 2013, 46 (14), pp.5512-5519. 10.1021/ma400539s . hal-02908806

\section{HAL Id: hal-02908806 https://hal.science/hal-02908806}

Submitted on 2 Mar 2021

HAL is a multi-disciplinary open access archive for the deposit and dissemination of scientific research documents, whether they are published or not. The documents may come from teaching and research institutions in France or abroad, or from public or private research centers.
L'archive ouverte pluridisciplinaire HAL, est destinée au dépôt et à la diffusion de documents scientifiques de niveau recherche, publiés ou non, émanant des établissements d'enseignement et de recherche français ou étrangers, des laboratoires publics ou privés. 


\section{Reversible-Deactivation Radical Polymerization of}

\section{Methyl Methacrylate and Styrene Mediated by Alkyl}

\section{Dithiocarbamates and Copper Acetylacetonates}

Yaozhong Zhang, Kristin Schröder, Yungwan Kwak, ${ }^{\dagger}$ Pawel Krys, Aurélie N. Morin, Tomislav

Pintauer, ${ }^{, \pm \pm}$Rinaldo Poli, ${ }^{,+s}$ and Krzysztof Matyjaszewski*

Center for Macromolecular Engineering, Department of Chemistry, Carnegie Mellon University, 4400 Fifth Avenue, Pittsburgh, PA, 15213.

$\dagger$ Silberline Manufacturing Co., Inc., 36 Progressive Avenue, Tamaqua, PA, 18252.

† Laboratoire de Chimie de Coordination (LCC), CNRS 8241, Université de Toulouse; UPS, INPT, 205 Route de Narbonne, 31077 Toulouse, France.

${ }^{ \pm}$Department of Chemistry and Biochemistry, Duquesne University, 600 Forbes Avenue, 308 Mellon Hall, Pittsburgh, Pennsylvania 15282, USA.

$\S$ Institut Universitaire de France 103, bd Saint-Michel, 75005 Paris, France

ABSTRACT. Reversible-deactivation radical polymerization (RDRP) of methyl methacrylate (MMA) and styrene (St) were successfully mediated by copper(II) acetylacetonate, [Cu(acac)2], or copper(II) hexafluoroacetylacetonate, $\left[\mathrm{Cu}(\mathrm{hfa})_{2}\right]$, in conjunction with 1-cyano-1-methylethyl 
diethyldithiocarbamate (MAN-DC) or 2-(N,N-diethyldithiocarbamyl) ethyl isobutyrate (EMADC) initiators/transfer agents in the absence of additional reducing agents. Linear first order kinetic plots were obtained for the polymerization of MMA in the presence of $\left[\mathrm{Cu}(\mathrm{hfa})_{2}\right]$ or $\left[\mathrm{Cu}(\mathrm{acac})_{2}\right]$ and MAN-DC. [Cu(hfa $\left.)_{2}\right]$ provided better control than $\left[\mathrm{Cu}(\mathrm{acac})_{2}\right]$ for the polymerization of MMA, leading to PMMA with narrow molecular weight distribution, $M_{\mathrm{w}} / M_{\mathrm{n}} \sim$ 1.1. Polymerization of St was successfully carried out with either MAN-DC or EMA-DC in the presence of $\left[\mathrm{Cu}(\mathrm{hfa})_{2}\right]$, also resulting in polymers with low $M_{\mathrm{w}} / M_{\mathrm{n}}$ values. In the absence of alkyl dithiocarbamates or copper acetylacetonates, the polymerizations resulted in only trace amounts of polymers or polymers with high values of $M_{\mathrm{w}} / M_{\mathrm{n}}$. Thus, the combination of alkyl dithiocarbamates and copper(II) acetylacetonates provides a convenient way to prepare wellcontrolled PMMA and PSt. NMR analysis of low MW polymers reveals the presence of DC groups as chain ends. DFT calculations show that DC group transfer from a H-MMA-DC model of the growing chain to the $\mathrm{Cu}(\mathrm{II})$ complexes is energetically accessible and more favorable than $\mathrm{Br}$ atom transfer, thus rationalizing the need for the $\mathrm{Cu}(\mathrm{II}) /$ dithiocarbamate combination for successful control and suggesting that the process takes place by reversible DC group transfer involving a $\mathrm{Cu}^{\mathrm{II}} / \mathrm{Cu}^{\mathrm{III}}$ couple. Attempts to synthesize complexes $\left[\mathrm{Cu}(\mathrm{acac})_{2}(\mathrm{DC})\right]$ and $\left[\mathrm{Cu}(\mathrm{hfa})_{2}(\mathrm{DC})\right]$, in combination with DFT calculations, suggests that these complexes are

thermodynamically unstable relative to the bis(diketonate)copper(II) and dithiuram disulfide, but this does not preclude the involvement of the $\mathrm{Cu}(\mathrm{III})$ species as a spin trap in RDRP controlled by DC group transfer.

\section{INTRODUCTION.}

Reversible-deactivation radical polymerizations (RDRP) procedures are powerful techniques for synthesizing functional homo- and block (co)polymers with different architectures under 
mild conditions. (I don't like the word procedure. It is a methodology or technique). ${ }^{1}$ Typical RDRP processes include stable free radical polymerization $(\mathrm{SFRP}),{ }^{2}$ atom transfer radical polymerization (ATRP), ${ }^{3}$ and reversible addition-fragmentation chain transfer (RAFT), an example of a degenerative transfer (DT) process $^{4}$ (Scheme 1). All RDRP processes rely on a dynamic equilibrium between dormant species and propagating radicals, which plays a pivotal role enabling formation of polymers with narrow molecular weight distribution (MWD) and predetermined molecular weights and additionally allows design and precise control of molecular architecture and topology. ${ }^{4 \mathrm{~g}, 5}$

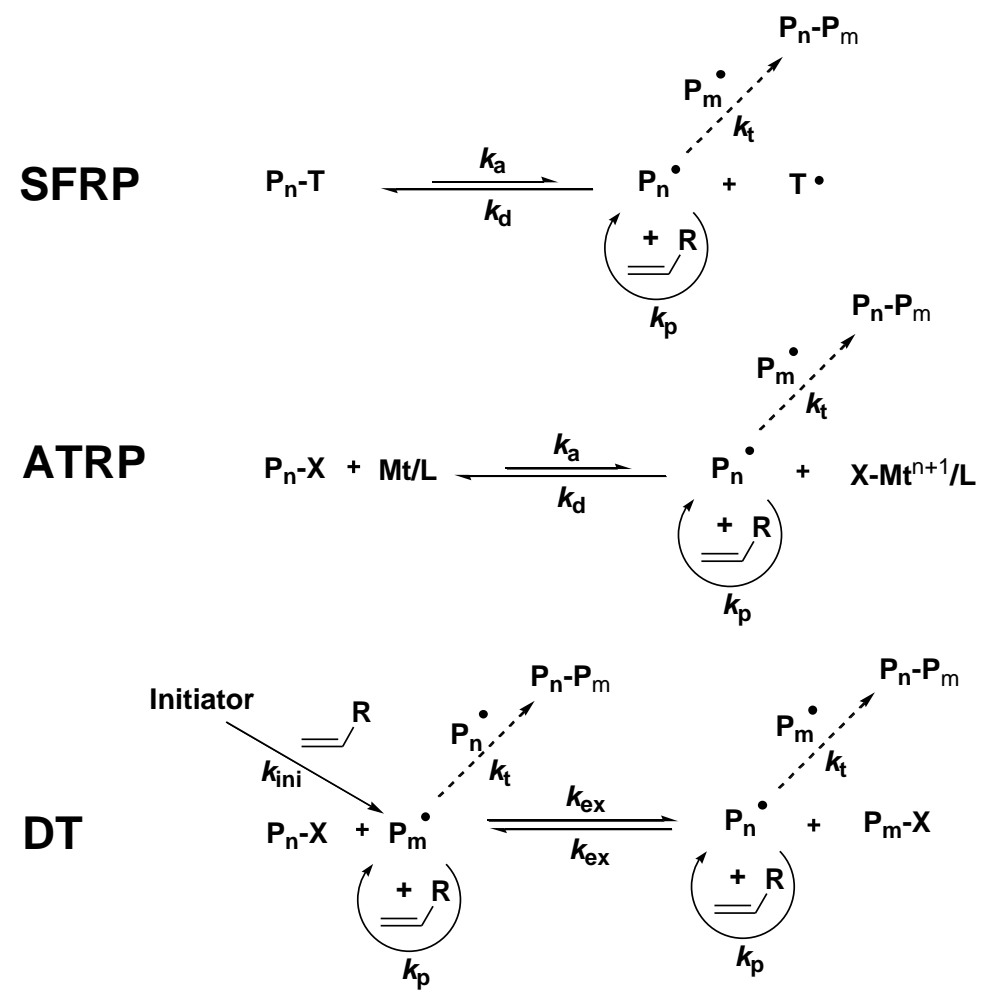

Scheme 1. Examples of RDRPs: SFRP, ATRP, and DT polymerization.

The first SFRP procedure employed iniferters that "induce a radical polymerization that proceeds via initiation, propagation, primary radical termination, and transfer to initiator". ${ }^{6}$ 
Originally dithiocarbamates were used for polymerization of styrene (St) and methyl methacrylate (MMA) yielding relatively poorly controlled polymers with broad MWD. This was due to a very slow exchange process between the propagating radicals and the dormant species. Subsequently, more efficient SFRP processes were invented, including nitroxide-mediated polymerizations, ${ }^{2 a}$ and organometallic mediated radical polymerization based e.g. on cobalt systems, such as cobalt porphyrins and cobalt acetylacetonate derivatives. ${ }^{7}$

ATRP, in which alkyl halides or pseudohalides act as initiators/dormant species that are intermittently activated by transition metal complexes, ${ }^{3 a, 8}$ enables the synthesis of a wide range of polymers with predetermined structures. The dynamic reversible equilibrium between dormant alkyl halides $\left(\mathrm{P}_{\mathrm{n}}-\mathrm{X}\right)$ and lower oxidation state transition metal complexes $\left(\mathrm{Mt}^{\mathrm{n}} / \mathrm{L}\right)$, and the respective propagating radicals $\left(\mathrm{P}_{n}{ }^{\bullet}\right)$ and higher oxidation state transition metal complexes $\left(\mathrm{X}-\mathrm{Mt}^{\mathrm{n}+1} / \mathrm{L}\right)$ is maintained during the ATRP process, as indicated or shown in Scheme 1. Both SFRP and ATRP are based on the persistent radical effect. ${ }^{9}$ Recent improvements in ATRP have focused on diminishing the catalyst loading to a few parts per million, as discussed in activators regenerated by electron transfer (ARGET) ATRP, ${ }^{10}$ initiators for continuous activator regeneration (ICAR) ATRP, ${ }^{11} e$ ATRP $^{12}$ and photoATRP. ${ }^{13}$

RAFT polymerization employs a fast degenerative exchange between various dithio compounds, serving as dormant species, and radicals that must be continuously supplied to the system. $^{4 b, 4 c}$ Recently, concurrent ATRP/RAFT processes were reported which involved the direct activation of chain transfer agents (CTA)/ (alkyl pseudohalides) initiators with a $\mathrm{Cu}$ X/L $(\mathrm{X}=\mathrm{Br}$ or $\mathrm{Cl} ; \mathrm{L}=N$-donor ligand) catalyst that allowed the reaction to proceed without addition of conventional radical initiators, ${ }^{14}$ such as AIBN. Various halogen-free (pseudohalide) initiators 
were successfully employed, e.g. alkyl dithiocarbamates (DCs). ${ }^{15}$ Well-controlled PMMA and PSt were obtained with narrow MWD. ${ }^{15 b}$

It must be stressed that a successful RAFT process requires appropriate selection of a leaving group and radical stabilizing group in dithio compound to match monomer reactivity. ${ }^{4 c}$ For example, dithiocarbamates are excellent transfer agents for less reactive monomers such as vinyl acetate or $N$-vinyl pyrrolidone but very poor agents for St or MMA, thereby explaining the relatively low degree of control in the original iniferter systems. ${ }^{6 \mathrm{~b}}$ Concurrent ATRP/RAFT processes permit a more relaxed selection of initiators/ CTAs. Therefore, some previously poorly controlled RAFT systems, e.g. dithiocarbamates / MMA, were converted to well-controlled polymerizations in the presence of appropriate $\mathrm{Cu}^{\mathrm{I}}$ catalyst/mediating agents.

As part of a continued search for new $\mathrm{Cu}$ species for this process, we explored the viability of using $\mathrm{Cu}^{\mathrm{II}}$ acetylacetonates. Some metal acetylacetonates, such as $\mathrm{Cu}(\mathrm{acac})_{2}, \mathrm{Co}(\mathrm{acac})_{3}$, and $\mathrm{Mn}(\mathrm{acac})_{3}$, have been reported as free radical initiators ${ }^{16}$ for the polymerization of vinyl chloride, ${ }^{17} \mathrm{St},{ }^{18}$ and $\mathrm{MMA},{ }^{19}$ yielding polymers with high $\mathrm{MW}$ and broad MWD. $\mathrm{Cu}(\mathrm{acac})_{2}$ has also been employed as a catalyst for other processes, such as ring-opening cycloisomerization, ${ }^{20}$ or cyclopropanation. ${ }^{21}$

Herein, we report the synthesis of well-controlled PMMA and PSt, using 1-cyano-1methylethyldiethyldithiocarbamate (MAN-DC) or 2-(N,N-diethyldithiocarbamyl) ethyl isobutyrate (EMA-DC) as initiators/transfer agents in the presence of oxidatively stable copper(II) acetylacetonates at 80 and $120^{\circ} \mathrm{C}$ (Scheme 2) (or between 80 and 120 oC). Surprisingly, these reactions did not require any reducing agents to convert $\mathrm{Cu}^{\mathrm{II}}$ species to $\mathrm{Cu}^{\mathrm{I}}$, used previously in concurrent ATRP/RAFT. 
n<smiles>C=C(C)C(=C)OC</smiles>

n<smiles>C=Cc1ccccc1</smiles>
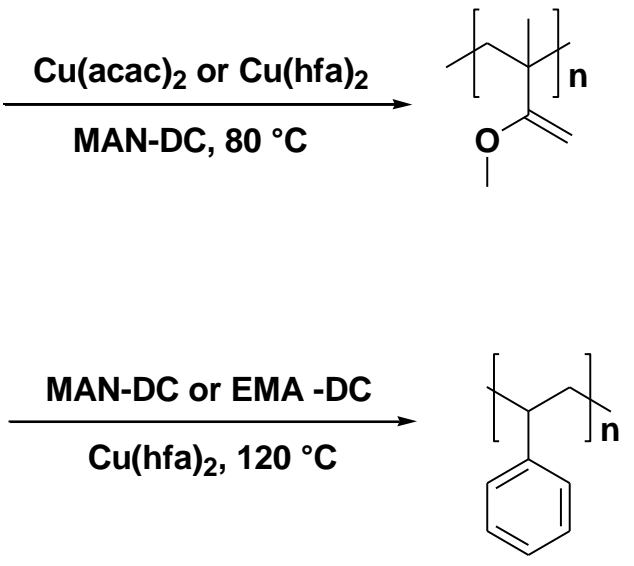

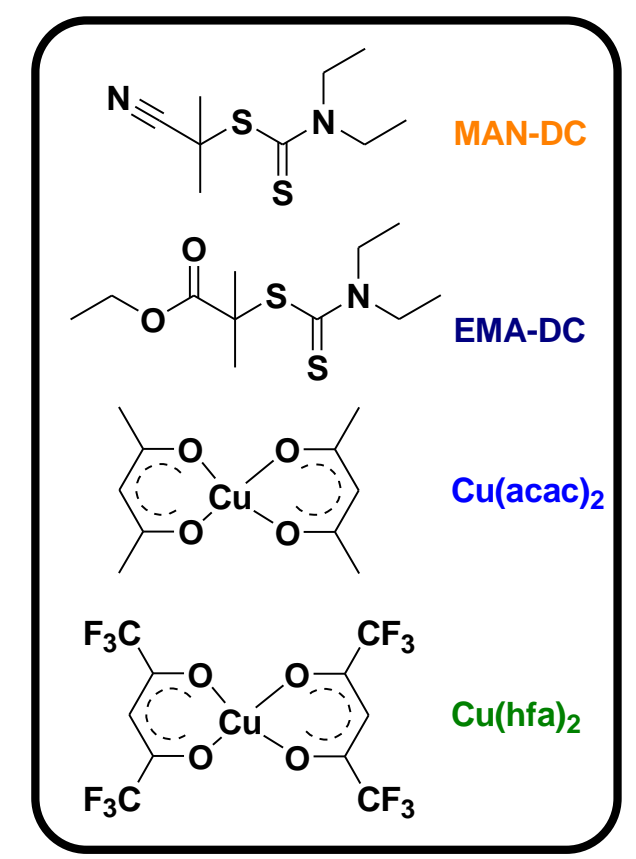

Scheme 2. Reversible-deactivation radical polymerization of MMA and styrene with MANDC/EMA-DC and $\left[\mathrm{Cu}(\mathrm{acac})_{2}\right] /\left[\mathrm{Cu}(\mathrm{hfa})_{2}\right]$.

\section{RESULTS AND DISCUSSION.}

\section{(a) Polymerizations}

Polymerization of MMA. Initially, polymerization of MMA with MAN-DC as initiator and $\left[\mathrm{Cu}(\mathrm{acac})_{2}\right]$ was studied, targeting a degree of polymerization (DP) of 400, as shown in Figure S1. The resulting PMMA had broad MWD $\left(M_{\mathrm{w}} / M_{\mathrm{n}} \sim 1.5\right)$ and experimental molecular weights $\left(M_{\mathrm{n}, \exp }\right)$ were higher than theoretical ones $\left(M_{\mathrm{n}, \text { theo }}\right)$ (Entries 1-4 in Table 1, Figure $\left.\mathrm{S} 1 \mathrm{~b}\right)$. Furthermore, $M_{\mathrm{n}}$ did not increase with conversion, indicating inefficient deactivation and a similarity of the reaction with conventional radical polymerization. Nevertheless, the presence of a higher concentration of $\left[\mathrm{Cu}(\mathrm{acac})_{2}\right]$, as in Figure $\mathrm{S} 1 \mathrm{a}$, resulted in an increase of the polymerization rate, suggesting a catalytic process for radical generation, even though an 
oxidatively stable $\mathrm{Cu}^{\mathrm{II}}$ species was used rather than $\mathrm{Cu}^{\mathrm{I}}$, and no reducing agent was added to the reaction.

Subsequently, the polymerization of MMA mediated by $\left[\mathrm{Cu}(\mathrm{hfa})_{2}\right]$ was studied. Figure 1 and entries 5-9 in Table 1 present the results of a polymerization conducted in bulk at $80{ }^{\circ} \mathrm{C}$. Linear first order kinetic plots were obtained, which indicated a constant concentration of propagating radicals in the system (Figure 1a). The employed ratio of $\left[\mathrm{Cu}(\mathrm{hfa})_{2}\right]_{0} /[\mathrm{MAN}-\mathrm{DC}]_{0}$ was similar to $\left[\mathrm{Cu}(\mathrm{acac})_{2}\right]$ system; an increase in polymerization rates was observed at higher copper loadings. The apparent propagation rate constant $\left(k_{\mathrm{app}}\right)$ scaled to $\left[\mathrm{Cu}(\mathrm{hfa})_{2}\right] 0_{0}^{0.64}$, as shown in Figure S2. In contrast to $\left[\mathrm{Cu}(\mathrm{acac})_{2}\right]$, the $\left[\mathrm{Cu}(\mathrm{hfa})_{2}\right]$ system showed excellent correlation between $M_{\mathrm{n}, \exp }$ and $M_{\mathrm{n}, \text { theo, }}$ indicating high initiation efficiency for the polymerization (Figure 1b). The MWD of PMMA synthesized with $\left[\mathrm{Cu}(\mathrm{hfa})_{2}\right]$ decreased with monomer conversion, as expected for a wellcontrolled polymerization, and reached values as low as 1.1 .
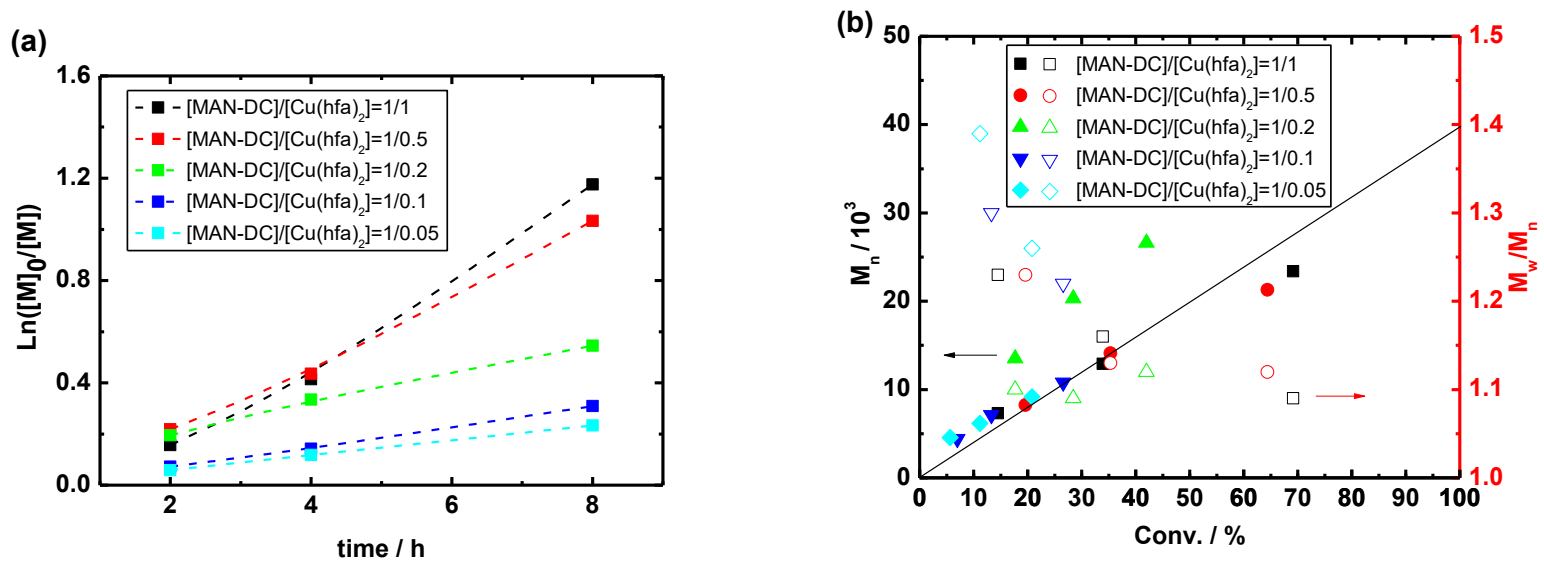

Figure 1. (a) Kinetic plots of $\ln \left([\mathrm{M}]_{0} /[\mathrm{M}]\right)$ vs. time; (b) plot of $M_{\mathrm{n}}$ and $M_{\mathrm{w}} / M_{\mathrm{n}}$ values $v s$. conversion for MMA/MAN-DC/[Cu(hfa $\left.)_{2}\right]=400 / 1 / \mathrm{X}$ at $80{ }^{\circ} \mathrm{C}$ in bulk.

Under the same conditions, $[\mathrm{MMA}]_{0}:[\mathrm{MAN}-\mathrm{DC}]_{0}:\left[\mathrm{Cu}^{\mathrm{II}}\right]_{0}=400 / 1 / 0.2$, polymerization with $\left[\mathrm{Cu}(\mathrm{acac})_{2}\right]$ was faster than with $\left[\mathrm{Cu}(\mathrm{hfa})_{2}\right], k_{\mathrm{app}}=0.111 \mathrm{~h}^{-1}$ and $k_{\mathrm{app}}=0.0576 \mathrm{~h}^{-1}$, respectively, 
indicating that the radical concentration in the $\left[\mathrm{Cu}(\mathrm{acac})_{2}\right]$ system was about twice higher than with $\left[\mathrm{Cu}(\mathrm{hfa})_{2}\right]$. The higher concentration of radicals in the $\left[\mathrm{Cu}(\mathrm{acac})_{2}\right]$ system could lead to the higher $M_{\mathrm{w}} / M_{\mathrm{n}}$ values. In order to improve the level of control, and to determine the influence of temperature on the polymerization of MMA with $\left[\mathrm{Cu}(\mathrm{acac})_{2}\right]$ and MAN-DC, polymerizations were performed at lower temperatures with a ratio of $[\mathrm{MMA}]_{0} /[\mathrm{MAN}-\mathrm{DC}]_{0} /\left[\mathrm{Cu}(\mathrm{acac})_{2}\right]_{0}=$ 400/1/0.05 (Figure S3). The polymerization rate decreased at lower temperatures, but MWD did not change significantly, $M_{\mathrm{w}} / M_{\mathrm{n}}=\sim 1.5$.

Table 1. Results for the polymerization of MMA and St with $\left[\mathrm{Cu}(\mathrm{acac})_{2}\right]$ or $\left[\mathrm{Cu}(\mathrm{hfa})_{2}\right]$

\begin{tabular}{|c|c|c|c|c|c|c|c|c|c|c|}
\hline Entry & Monomer & Initiator & $\begin{array}{l}\mathrm{Cu}- \\
\text { species }^{\mathrm{a}}\end{array}$ & $\begin{array}{l}{[\mathrm{Cu}]_{0} /} \\
{[\text { Initiator }]_{0}}\end{array}$ & $\begin{array}{l}\mathrm{T} \\
\left({ }^{\circ} \mathrm{C}\right)\end{array}$ & $\begin{array}{l}\text { Time } \\
\text { (h) }\end{array}$ & $\begin{array}{l}\text { Conv. } \\
(\%)\end{array}$ & $M_{\mathrm{n}, \text { theo }}$ & $M_{\mathrm{n}, \mathrm{GPC}}$ & $M_{\mathrm{w}} / M_{\mathrm{n}}$ \\
\hline $1^{\mathrm{b}}$ & MMA & $\begin{array}{l}\text { MAN- } \\
\text { DC }\end{array}$ & 1 & 0.01 & 80 & 8 & 28 & 11,200 & 28,000 & 1.57 \\
\hline $2^{\mathrm{b}}$ & MMA & $\begin{array}{l}\text { MAN- } \\
\text { DC }\end{array}$ & 1 & 0.02 & 80 & 8 & 36 & 14,400 & 27,500 & 1.51 \\
\hline $3^{\mathrm{b}}$ & MMA & $\begin{array}{l}\text { MAN- } \\
\text { DC }\end{array}$ & 1 & 0.05 & 80 & 8 & 46 & 18,400 & 27,300 & 1.54 \\
\hline $4^{\mathrm{b}}$ & MMA & $\begin{array}{l}\text { MAN- } \\
\text { DC }\end{array}$ & 1 & 0.2 & 80 & 8 & 55 & 22,000 & 23,800 & 1.53 \\
\hline $5^{\mathrm{b}}$ & MMA & $\begin{array}{l}\text { MAN- } \\
\text { DC }\end{array}$ & 2 & 0.05 & 80 & 8 & 21 & 8,400 & 9,200 & 1.26 \\
\hline $6^{\mathrm{b}}$ & MMA & $\begin{array}{l}\text { MAN- } \\
\text { DC }\end{array}$ & 2 & 0.1 & 80 & 8 & 27 & 10,800 & 10,800 & 1.22 \\
\hline $7^{\mathrm{b}}$ & MMA & $\begin{array}{l}\text { MAN- } \\
\text { DC }\end{array}$ & 2 & 0.2 & 80 & 8 & 42 & 16,800 & 26,600 & 1.12 \\
\hline $8^{\mathrm{b}}$ & MMA & $\begin{array}{l}\text { MAN- } \\
\text { DC }\end{array}$ & 2 & 0.5 & 80 & 8 & 64 & 25,600 & 21,300 & 1.12 \\
\hline $9^{b}$ & MMA & $\begin{array}{l}\text { MAN- } \\
\text { DC }\end{array}$ & 2 & 1 & 80 & 8 & 69 & 27,600 & 23,400 & 1.09 \\
\hline
\end{tabular}




\begin{tabular}{|c|c|c|c|c|c|c|c|c|c|c|}
\hline $10^{\mathrm{c}}$ & St & $\begin{array}{l}\text { MAN- } \\
\text { DC }\end{array}$ & 2 & 1 & 120 & 22 & 99 & 20,600 & 33,500 & 1.20 \\
\hline $11^{\mathrm{c}}$ & $\mathrm{St}$ & $\begin{array}{l}\text { EMA- } \\
\text { DC }\end{array}$ & 2 & 1 & 120 & 8 & 92 & 18,400 & 29,700 & 1.15 \\
\hline $12^{\mathrm{c}}$ & MMA & EBPA & 2 & 1 & 80 & 46 & Trace & - & - & - \\
\hline $13^{c}$ & MMA & EBPA & 1 & 1 & 80 & 23 & 51 & 10,200 & 93,400 & 2.32 \\
\hline $14^{\mathrm{c}}$ & St & EBPA & 1 & 1 & 120 & 25 & 84 & 17,500 & 9,400 & 2.01 \\
\hline $15^{\mathrm{c}}$ & St & EBPA & 2 & 1 & 120 & 25 & 45 & 9,300 & 10,900 & 7.59 \\
\hline $16^{\mathrm{b}}$ & MMA & $\begin{array}{l}\text { MAN- } \\
\text { DC }\end{array}$ & none & - & 80 & 12 & 30 & 12,000 & 185,000 & 2.14 \\
\hline $17^{b}$ & MMA & $\begin{array}{l}\text { MAN- } \\
\text { DC }\end{array}$ & AIBN & $0.5^{\mathrm{d}}$ & 80 & 1 & $\sim 100$ & 40,000 & 78,400 & 1.91 \\
\hline $18^{\mathrm{b}}$ & MMA & AIBN & 2 & $2^{\mathrm{e}}$ & 80 & 1 & $\sim 100$ & 40,000 & 99,000 & 2.14 \\
\hline
\end{tabular}

Chain Extension Experiments and Polymerization of St. The living character of the synthesized PMMA was demonstrated by chain extension with MMA from a PMMA macroinitiator $\left(M_{\mathrm{n}}=6000, M_{\mathrm{w}} / M_{\mathrm{n}}=1.39\right.$, prepared by a polymerization with $\left.\left[\mathrm{Cu}(\mathrm{hfa})_{2}\right]\right)$. Chain extension was carried out at $80{ }^{\circ} \mathrm{C}$ with a ratio of MMA $/$ macroinitiator $/\left[\mathrm{Cu}(\mathrm{hfa})_{2}\right]=800 / 1 / 1$. After $15 \mathrm{~h}$ reaction, a chain extended PMMA with $M_{\mathrm{n}}=57600, M_{\mathrm{w}} / M_{\mathrm{n}}=1.18$ was prepared, indicating an initiation efficiency $I_{\text {eff }}=96 \%$, without any detectable unreacted macroinitiator remaining (Figure 2). This result demonstrates that the synthesized PMMA maintains the ability for highly efficient chain-extension reactions, which is a requirement for well-controlled reversible-deactivation radical polymerization processes. 


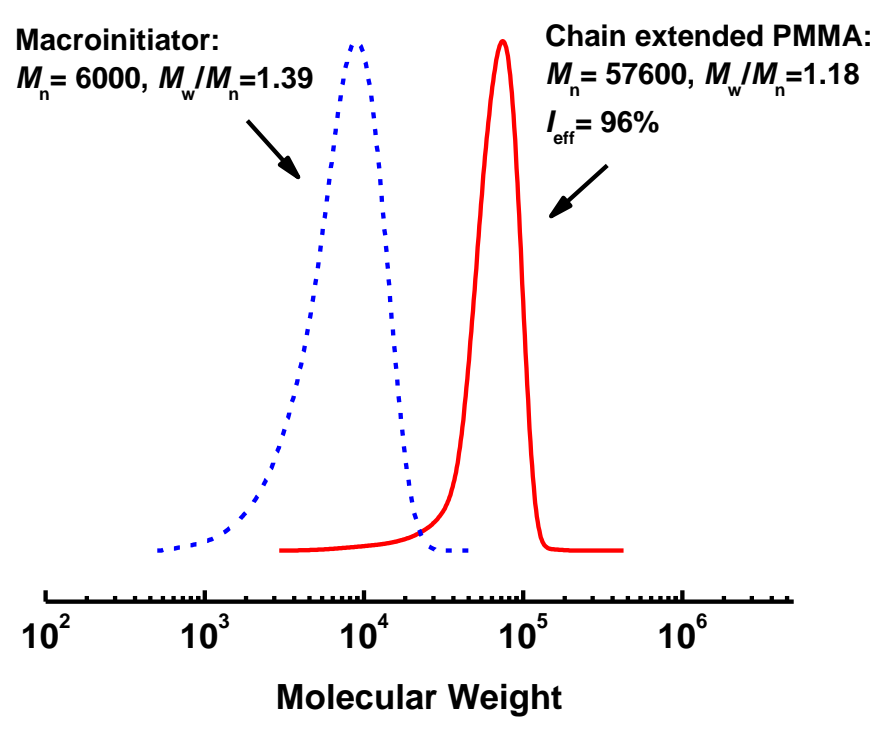

Figure 2. Chain extension of PMMA as a macroinitiator with MMA and [Cu(hfa) $)_{2}$.

Polymerization of styrene was also studied using alkyl dithiocarbamates and $\left[\mathrm{Cu}(\mathrm{hfa})_{2}\right]$. Although PSt samples with narrow MWD $\left(M_{\mathrm{w}} / M_{\mathrm{n}}<1.2\right)$ were obtained, $M_{\mathrm{n}, \exp }$ values of the resulting polymers were higher than the theoretical values regardless of initiator type, steh as, MAN-DC or EMA-DC (Entries 10-11 in Table 1). This could suggest decomposition of some of the initiators at elevated temperatures $\left(120^{\circ} \mathrm{C}\right)$.

Effect of the Structure of Initiator and Cu Compound. To further study the effect of the iniferter initiator, polymerizations with typical ATRP initiator ethyl $\alpha$-bromophenylacetate (EBPA) were examined (Entries 12-15 in Table 1). Polymerizations of MMA with [Cu(hfa) $)_{2}$ resulted in trace amount of PMMA. However, polymerizations with $\left[\mathrm{Cu}(\mathrm{acac})_{2}\right]$ showed higher conversions than with $\left[\mathrm{Cu}(\mathrm{hfa})_{2}\right]$. These results points to a faster radical producing process for $\left[\mathrm{Cu}(\mathrm{acac})_{2}\right]$ than for $\left[\mathrm{Cu}(\mathrm{hfa})_{2}\right]$. Yields were higher for styrene polymerization, presumably due 
to its thermal self-initiation at higher temperature and longer reaction times $(25 \mathrm{~h})$. Lower molecular weights indicate that additional chains were formed by thermal self-initiation. Regardless, all polymers had very broad molecular weight distributions $\left(M_{\mathrm{w}} / M_{\mathrm{n}}>2.0\right)$.

In order to test the role of the copper species, MMA was polymerized in the presence of only alkyl dithiocarbamate, without $\mathrm{Cu}$ species (Entry 16 in Table 1). High molecular weight polymer with a broad MWD $\left(M_{\mathrm{w}} / M_{\mathrm{n}} \sim 2.1\right)$ excludes a SFRP/DT mechanism for control, as previously reported. ${ }^{6 b}$ To test the possibility of a RAFT type process, polymerization of MMA with MANDC and 2,2'-azobisisobutyronitrile (AIBN) was carried out (Entry 17 in Table 1) (should be 2,2'). High molecular weight polymers with broad MWD were obtained already after one hour, indicating typical behavior of conventional radical polymerization with insufficient contribution of exchange. Polymerization with AIBN and $\left[\mathrm{Cu}(\mathrm{hfa})_{2}\right]$ behaved in a similar manner (see entry 18 in Table 1). These results clearly indicate that the presence of both MAN-DC/EMA-DC and $\left[\mathrm{Cu}(\mathrm{acac})_{2}\right] /\left[\mathrm{Cu}(\mathrm{hfa})_{2}\right]$ is necessary to achieve RDRP behavior.

End-Group Analysis. To confirm the role of the dithiocarbamate moiety as (pseudo)halide transferring group, shorter polymer chains were prepared and examined by end-group analysis. Reaction conditions for the polymerization of St and MMA were similar to those used previously (Table 1, entries 9-11). The reactions were stopped at early monomer conversions and the resulting PSt and PMMA were purified and analyzed by GPC, ${ }^{1} \mathrm{H}$ NMR, ${ }^{19} \mathrm{~F}$ NMR and MALDITOF MS. ${ }^{1} \mathrm{H}$ NMR spectra (Figure S5) confirmed characteristic DC end-group signals (diethylamine end groups $-\mathrm{N}-\mathrm{CH}_{2}-\mathrm{CH}_{3}, \sigma(\mathrm{ppm})$ : 3.6-4.0). DP calculated by integration signals of these end-groups in ${ }^{1} \mathrm{H}$ NMR agrees well with DP obtained from GPC measurements (Table 2). Furthermore, MALDI-TOF MS of PSt (Table 2, entries 1-2) was investigated. The spectra (Figure S6) confirmed the dominant presence of cyanoisopropyl or ethyl isobutyrate initiated 
polymer chains (with Ag or Na cations). In addition, a second minor series was observed in both spectra. They could be assigned to either $\left[(\mathrm{St})_{\mathrm{n}}+\mathrm{Ag}^{+}\right]$, resulting from thermally self-initiated chains at $120{ }^{\circ} \mathrm{C}$, or to $\left[\mathrm{hfa}-(\mathrm{St})_{\mathrm{n}-2}+\mathrm{Ag}^{+}\right]$. However, ${ }^{19} \mathrm{~F}$ NMR of PSt samples showed no signals, eliminating this possibility and incorporation of hfa groups into polymers.

Table 2. Characterization of shorter polymer chains

\begin{tabular}{ccccccc}
\hline Entry & Monomer & Initiator & $M_{\mathrm{n}, \mathrm{GPC}}{ }^{\mathrm{a}}$ & $M_{\mathrm{w} /} M_{\mathrm{n}, \mathrm{GPC}} \mathrm{DP}^{\mathrm{a}} \mathrm{GPC}^{\mathrm{a}}$ & $\mathrm{DP}, \mathrm{NMR}^{\mathrm{b}}$ \\
\hline 1 & St & MAN-DC & $6.53 * 10^{3}$ & 1.08 & $\sim 63$ & $\sim 57$ \\
2 & St & EMA-DC & $4.71 * 10^{3}$ & 1.13 & $\sim 45$ & $\sim 47$ \\
3 & MMA & MAN-DC & $6.06^{*} 10^{3}$ & 1.28 & $\sim 60$ & $\sim 59$ \\
\hline
\end{tabular}

a Determined by size exclusion chromatography in THF using polystyrene standards, ${ }^{\mathrm{b}}$ Determined by ${ }^{1} \mathrm{H} \mathrm{NMR}$ in $\mathrm{CDCl}_{3}$

\section{(b) Mechanistic Investigations}

As mentioned before, ATRP is typically mediated by $\mathrm{Cu}^{\mathrm{I}}$ species as activators and $\mathrm{Cu}^{\mathrm{II}}$ species act as deactivators. Thus, the latter must be first reduced to initiate ATRP. This can happen by light, electrical current, ligands or even monomer. ${ }^{13-14,14 \mathrm{~d}, 22}$ It is possible that $\mathrm{Cu}^{\mathrm{II}}$ acetylacetonates are not stable at elevated temperatures and are in situ reduced to some active $\mathrm{Cu}^{\mathrm{I}}$ species, assisted by dithiocarbamates (Scheme 3A). Indeed, decomposition of [Cu(acac $\left.)_{2}\right]$ assisted by water vapors under harsh conditions, resulting in the oxidized acac ligand and $\mathrm{Cu}$ or $\mathrm{Cu}_{2} \mathrm{O}$ was reported. ${ }^{23}$ Also, the homolysis of metal-oxygen bonds in metal acetylacetonates, producing acetylacetonate radicals, was proposed. ${ }^{16 a, 18}$ Decomposition of $\gamma$-substituted (but-1enyl) $\left[\mathrm{Cu}(\mathrm{acac})_{2}\right]$ resulted in polymerization of MMA. ${ }^{19,24}$ Thus, an attempt to observe the decomposition $\left[\mathrm{Cu}(\mathrm{acac})_{2}\right]$ via UV-Vis was conducted. However, the decrease in the UV signal intensity of $\left[\mathrm{Cu}(\mathrm{acac})_{2}\right]$ at $650 \mathrm{~nm}$ in DMSO solution was very limited, only $7.4 \%$ after $23 \mathrm{~h}$, while no noticeable decrease of $\left[\mathrm{Cu}(\mathrm{hfa})_{2}\right]$ signal at $860 \mathrm{~nm}$ in DMSO solution was observed at $\mathrm{T}$ 
$=80{ }^{\circ} \mathrm{C}$ for nearly one day, as shown in Table S1 \& S2. Subsequently, polymerization of MMA with $\left[\mathrm{Cu}(\mathrm{acac})_{2}\right]$ but without alkyl dithiocarbamate initiator was conducted (Table S3). The $\left[\mathrm{Cu}(\mathrm{acac})_{2}\right]$ system resulted in only $9 \%$ monomer conversion after $44 \mathrm{~h}$, and the $\left[\mathrm{Cu}(\mathrm{hfa})_{2}\right]$ system produced nearly no polymer at $[\mathrm{MMA}]_{0} /\left[\mathrm{Cu}^{\mathrm{II}}\right]_{0}=200 / 1$. Thus, plausibly, copper(II) acetylacetonate could react with alkyl dithiocarbamate and form reversibly $\mathrm{Cu}^{\mathrm{III}}$ species or could decompose slowly at elevated temperatures and produce activators in situ (Scheme 3).

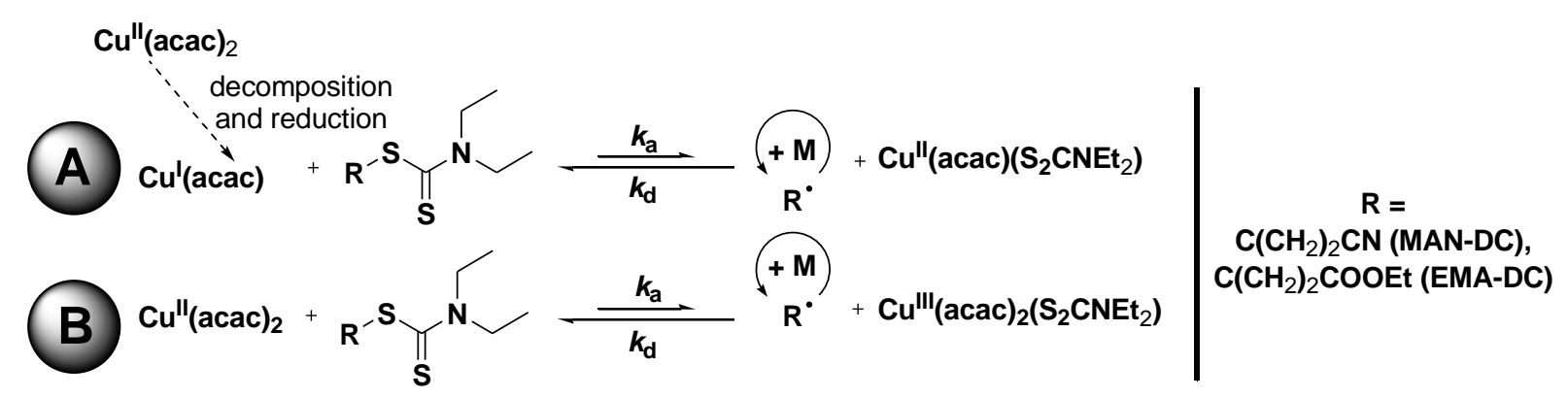

Scheme 3. Proposed putative mechanisms for the RDRP of MMA and St with copper(II) acetylacetonates and dithiocarbamates.

\section{Reaction of $\mathrm{Cu}^{\mathrm{II}}(\mathrm{acac})_{2}$ with thiuram disulfide.}

To further investigate the putative formation of a $\mathrm{Cu}^{\mathrm{III}}$ species, a reaction of $\left[\mathrm{Cu}(\mathrm{acac})_{2}\right]$ and tetramethylthiuram disulfide (DC-DC) was carried out, see scheme 4. The UV-Vis spectra recorded during the reaction are shown on Figure S4.

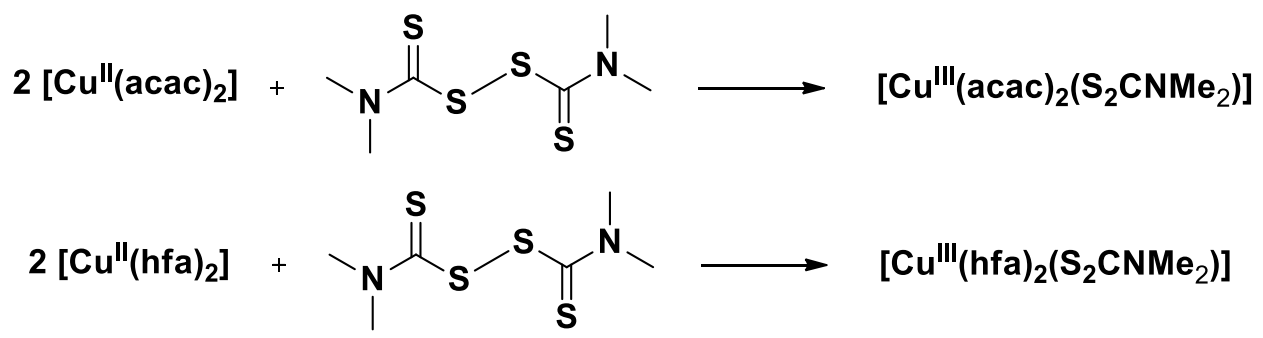

Scheme 4. Reactions carried out in order to probe the stability of $\mathrm{Cu}^{\mathrm{III}}-\mathrm{DC}$ species. 
The literature reports several examples of well characterized $\mathrm{Cu}^{\mathrm{III}}$-DC derivatives, for instance $\left[\left(\mathrm{C}_{6} \mathrm{~F}_{5}\right)_{2} \mathrm{Cu}(\mathrm{DC})\right]^{25},\left[\mathrm{CuX}_{2}(\mathrm{DC})\right](\mathrm{X}=\mathrm{Cl}, \mathrm{Br})^{26},\left[\mathrm{Cu}(\mathrm{DC})_{2}\right]^{+27}$, and the mixed-valence $\mathrm{Cu}^{\mathrm{II}} / \mathrm{Cu}^{\mathrm{III}}$ complex $\left[\mathrm{Cu}_{3}(\mathrm{DC})_{6}\right]^{2+28}$. The $\left[\mathrm{CuX}_{2}(\mathrm{DC})\right]$ complexes were obtained by straightforward oxidation of $\mathrm{CuX}_{2}$ by DC-DC, which occurs readily at $0^{\circ} \mathrm{C}^{26}$. Contrary to the latter reaction, however, we did not observe any fast reaction between $\left[\mathrm{Cu}(\mathrm{acac})_{2}\right]$ or $\left[\mathrm{Cu}(\mathrm{hfa})_{2}\right]$ and DC-DC at room temperature. The solutions changed color quite slowly at room temperature from blue to green (see Supporting information) and faster upon warming, eventually becoming very dark green. This transformation appeared faster from $\left[\mathrm{Cu}(\mathrm{hfa})_{2}\right]\left(4 \mathrm{~h}\right.$ at $\left.65^{\circ} \mathrm{C}\right)$ than from $\left[\mathrm{Cu}(\mathrm{acac})_{2}\right]$ ( $8 \mathrm{~h}$ at the THF reflux). Work up of the solution from the $\left[\mathrm{Cu}(\mathrm{hfa})_{2}\right]$ reaction, however, resulted only in the identification of the known $\left[\mathrm{Cu}\left(\mathrm{S}_{2} \mathrm{CNEt}_{2}\right)_{2}\right]$ after crystallization from $\mathrm{THF} /$ pentane and determination of the crystal unit cell, in comparison with that reported in the Cambridge Structural Database. $\{$ Bonamico, $1965 \# 97\}$ The nature of this observed product suggests that the slow reaction is accompanied by oxidation of the acetylacetonate ligand. Further attempts at generating $\mathrm{Cu}^{\mathrm{III}}$ species under photolytic conditions from $\left[\mathrm{Cu}^{\mathrm{II}}(\mathrm{acac})_{2}\right] / \mathrm{DC}-\mathrm{DC}$ or $\left[\mathrm{Cu}(\mathrm{Iffa})_{2}\right] / \mathrm{DC}-\mathrm{DC}$ at $-40^{\circ} \mathrm{C}$ resulted again in no reaction. Thus, these experiments suggest that $\left[\mathrm{Cu}^{\mathrm{III}}(\mathrm{acac})_{2}(\mathrm{DC})\right]$ is not thermodynamically stable relative to $\left[\mathrm{Cu}^{\mathrm{II}}(\mathrm{acac})_{2}\right]$ or $\left[\mathrm{Cu}{ }^{\mathrm{II}}(\mathrm{hfa})_{2}\right]$ and DC-DC. This result, however, does not preclude the involvement of the $\mathrm{Cu}^{\mathrm{III}}$ species in a controlled mechanism by DC group transfer (vide infra). The isolated $\left[\mathrm{Cu}(\mathrm{DC})_{2}\right]$ product that formed slowly during the thermal $\left[\mathrm{Cu}^{\mathrm{II}}(\mathrm{hfa})_{2}\right] / \mathrm{DC}-\mathrm{DC}$ reaction was tested as a controlling agent in the presence of MAN-DC for the MMA polymerization under the same conditions reported in Table $1\left(80^{\circ} \mathrm{C}\right.$, target $\left.\mathrm{DP}=240 ;[\mathrm{Cu}] / \mathrm{MAN}-\mathrm{DC}=1\right)$. No polymerization took place within the first $4 \mathrm{~h}$ and only $3 \%$ conversion was measured after $17 \mathrm{~h}(v s 69 \%$ after $8 \mathrm{~h}$ when using 
$\left.\left[\mathrm{Cu}(\mathrm{hfa})_{2}\right]\right)$. Therefore, the slow thermal decomposition of $\left[\mathrm{Cu}(\mathrm{hfa})_{2}\right]$ to $\left[\mathrm{Cu}(\mathrm{DC})_{2}\right]$ cannot account for the polymerization results in the presence of the former complex.

DFT calculations: choice of the model. The possibility of a DC group transfer equilibrium (e.g. B in Scheme 3) was probed by DFT calculations, which dealt with the equilibrium shown in Scheme 5. The equilibrium involves the combination of either $\left[\mathrm{Cu}(\mathrm{acac})_{2}\right]$ or $\left[\mathrm{Cu}(\mathrm{hfa})_{2}\right]$ and a $\mathrm{Me}_{2} \mathrm{C}(\mathrm{COOMe})-\mathrm{X}$ reagent where the $\mathrm{Me}_{2} \mathrm{C}(\mathrm{COOMe})$ group models the polymer radical chain PMMA $^{*}$ (i.e., the polymer chain beyond the ultimate monomer unit is replaced with an $\mathrm{H}$ atom), allowing simplification of the calculations of the reaction energetics. This simplification is likely to introduce a systematic error related to the penultimate effect, known to be important for the MMA polymerization ${ }^{29}$, and previously estimated by DFT calculations as $2-3 \mathrm{kcal} / \mathrm{mol}$ in $\Delta \mathrm{H}$ for MMA at room temperature depending on the nature of $\mathrm{X}(\mathrm{Cl} \text { or } \mathrm{Br})^{30}$. As the effect is steric and should be stronger in $\mathrm{X}-\mathrm{CMe}_{2}(\mathrm{COOMe})$ than in ${ }^{\circ} \mathrm{CMe}_{2}(\mathrm{COOMe})$, the equilibria will be calculated as too endothermic by only a few $\mathrm{kcal} / \mathrm{mol}$. However, this approximation will affect all the equilibria in a similar way and will have no dramatic effect on the conclusions of the study, which are based on the relative energy values for the different equilibria. The $\mathrm{X}$ atom/group in Scheme 5 was either $\mathrm{Br}$, to investigate the likelihood of a suitable ATRP controlling equilibrium, or $\mathrm{S}_{2} \mathrm{CNMe}$ to model the $\mathrm{DC}$ transfer equilibrium. The choice of $\mathrm{Me}$ instead of Et in the dithiocarbamate group allows lowering the computational cost without affecting the calculated bond energies. 


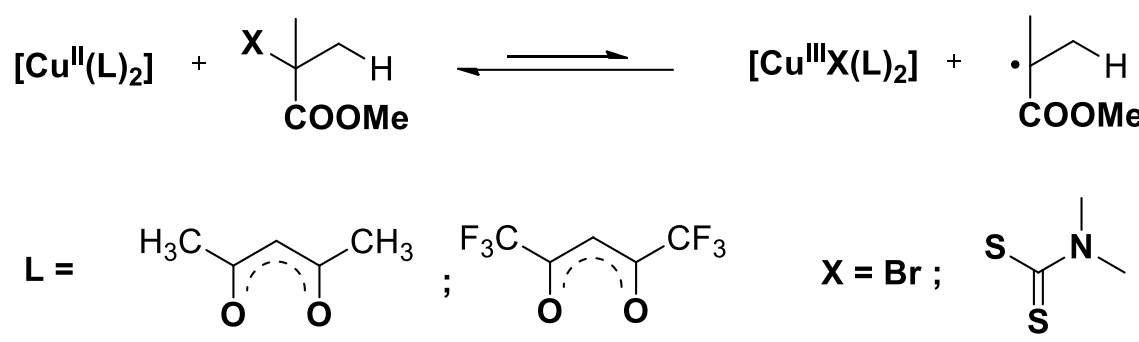

Scheme 5. Model equilibria investigated by the DFT calculations.

DFT calculations: geometries and energies. Images of all optimized geometries together with the Cartesian coordinates are available in the Supporting Information section. The geometries of the organic molecules $\mathrm{Br}-\mathrm{CMe}_{2}(\mathrm{COOMe}), \mathrm{Me}_{2} \mathrm{NCSS}-\mathrm{CMe}_{2}(\mathrm{COOMe})$ and ${ }^{\circ} \mathrm{CMe}_{2}(\mathrm{COOMe})$, already presented in a previous contribution ${ }^{31}$, were re-optimized at the level of theory chosen for the present contribution. The structure of $\mathrm{Me}_{2} \mathrm{NCSS}-\mathrm{SSCNMe}$, model of thiuram disulfide, has been optimized here for the first time. The geometries of $\left[\mathrm{Cu}(\mathrm{acac})_{2}\right]$ and $\left[\mathrm{Cu}(\mathrm{hfa})_{2}\right]$ converged to slightly distorted square planar structures, in agreement with the structures known experimentally from X-ray diffraction ${ }^{32}$. In terms of the $\mathrm{Cu}^{\mathrm{III}}$ species, a trigonal bipyramidal guess geometry was chosen for compounds $\left[\mathrm{Cu}^{\mathrm{III}}(\mathrm{acac})_{2} \mathrm{Br}\right]$ and $\left[\mathrm{Cu}^{\mathrm{III}}(\mathrm{hfa})_{2} \mathrm{Br}\right]$ on the basis of the known structure of $\left[\mathrm{Cu}^{\mathrm{III}}\left\{\mathrm{C}\left(\mathrm{S}-2-\mathrm{C}_{5} \mathrm{H}_{4} \mathrm{~N}\right)_{3}\right\} \mathrm{Cl}\right]^{+33}$ but converged to other geometries. The molecules were found more stable in a spin triplet ground state. Details of the molecular geometries are available in the Supporting Information

In terms of reaction energetic, the first point of interest concerns the energy changes associated to the oxidation of the $\mathrm{Cu}^{\mathrm{II}}$ complexes by DC-DC (Scheme 4). These are positive for both systems: for the acac system, 14.7 for $\Delta \mathrm{E}, 14.8$ for $\Delta \mathrm{H}$ and 19.0 for $\Delta \mathrm{G}$; for the hfa system, 7.6 for $\Delta \mathrm{E}, 7.8$ for $\Delta \mathrm{H}$ and 11.2 for $\Delta \mathrm{G}$. Therefore, the $\left[\mathrm{Cu}(\mathrm{hfa})_{2}\right]$ complex is predicted as slighly less hard to oxidize by $\mathrm{DC}-\mathrm{DC}$ than the $\left[\mathrm{Cu}(\mathrm{acac})_{2}\right]$ complex, but the oxidation remains thermodynamically unfavorable in both cases. This result is consistent with our inability to 
generate such $\mathrm{Cu}^{\mathrm{III}}$ products (vide supra). It is interesting to comment on this result, in relationship with the successful oxidation of $\mathrm{CuX}_{2}(\mathrm{X}=\mathrm{Cl}, \mathrm{Br})$ by $\mathrm{DC}-\mathrm{DC}$ to yield $\left[\mathrm{Cu}^{\mathrm{III}} \mathrm{X}_{2}(\mathrm{DC})\right]$. The energetic factor that tips the balance is probably the greater stability of the molecular tetracoordinated $\left[\mathrm{Cu}(\mathrm{acac})_{2}\right]$ and $\left[\mathrm{Cu}(\mathrm{hfa})_{2}\right]$ complexes, which contain four $\mathrm{Cu}^{\mathrm{II}}-\mathrm{O}$ bonds given the bidentate nature of the ligands. The cost of oxidizing the copper ion from II to

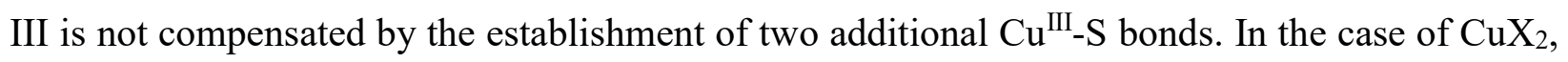
on the other hand, the starting materials structures consist of superimposed one-dimensional infinite $\left\{\mathrm{Cu}(\mu-\mathrm{X})_{2}\right\}_{\mathrm{n}}$ rods yielding an axially elongated octahedral configuration around each $\mathrm{Cu}^{\mathrm{II}}$ ion $^{34}$. Each $\mathrm{Cu}^{\mathrm{II}}-\mathrm{X}$ interaction is weaker than the $\mathrm{Cu}^{\mathrm{II}}-\mathrm{O}$ bonds in the bis(diketonates), which is also illustrated by the dissolution of the halides in water with complete ionization to $\left[\mathrm{Cu}\left(\mathrm{H}_{2} \mathrm{O}\right)_{6}\right]^{2+}\left(\mathrm{X}^{-}\right)_{2}$, whereas the two $\beta$-diketonates maintain their molecular nature in water and even spontaneously assemble from aqueous solutions of various $\mathrm{Cu}^{\mathrm{II}}$ salts and acetylacetone in the presence of weak bases ${ }^{32 a, 35}$. Thus, the energetic balance in the case of the $\mathrm{CuX}_{2}$ oxidation by DC-DC is more favorable because two very weak $\mathrm{Cu}^{\mathrm{II}}-\mathrm{X}$ bonds are replaced by stronger $\mathrm{Cu}^{\mathrm{II}}-\mathrm{S}$ bonds and give a favorable square planar geometry for the diamagnetic $d^{8} \mathrm{Cu}^{\mathrm{III}}$ ion ${ }^{26 \mathrm{~b}}$.

We now turn our attention to the energy changes related to the group transfer equilibria illustrated in Scheme 5 (Table 3). All equilibria are endothermic. For each compound, the cost of the atom or group transfer is lower when the product has a triplet state configuration, since all $\mathrm{Cu}^{\mathrm{III}}$ products are predicted as more stable as triplets at the chosen level of theory. However, the endothermicity is lower for the DC group transfer than for the $\mathrm{Br}$ atom transfer. This signifies that the DC group transfer from the RAFT transfer agent should occur more easily than the $\mathrm{Br}$ atom transfer from a classical ATRP initiator/dormant species. Thus, these results are consistent 
with the presence of controlled polymer growth in the presence of a dithiocarbamate initiator and with the absence of polymerization (for the hfa system) in the presence of a bromide initiator.

Table 3. Calculated equilibrium parameters $(\mathrm{kcal} / \mathrm{mol})$ for the atoms transfer or group transfer equilibria for the MMA polymerization mediated by $\left[\mathrm{Cu}(\mathrm{acac})_{2}\right]$ or $\left[\mathrm{Cu}(\mathrm{hfa})_{2}\right]$ and dithiocarbamate (Scheme 5).

\begin{tabular}{llllll|llllll}
$\mathrm{L}$ & $\mathrm{X}$ & $\mathrm{S}$ & $\Delta \mathrm{E}$ & $\Delta \mathrm{H}$ & $\Delta \mathrm{G}$ & $\mathrm{L}$ & $\mathrm{X}$ & $\mathrm{S}$ & $\Delta \mathrm{E}$ & $\Delta \mathrm{H}$ & $\Delta \mathrm{G}$ \\
\hline acac & $\mathrm{Br}$ & 0 & 52.9 & 51.5 & 48.9 & $\mathrm{hfa}$ & $\mathrm{Br}$ & 0 & 57.9 & 56.4 & 53.6 \\
acac & $\mathrm{Br}$ & 1 & 44.5 & 42.9 & 39.7 & $\mathrm{hfa}$ & $\mathrm{Br}$ & 1 & 49.3 & 47.1 & 45.2 \\
acac & $\mathrm{DC}$ & 0 & 50.8 & 48.8 & 44.1 & $\mathrm{hfa}$ & $\mathrm{DC}$ & 0 & 39.1 & 37.4 & 33.4 \\
acac & $\mathrm{DC}$ & 1 & 38.5 & 36.8 & 32.8 & $\mathrm{hfa}$ & $\mathrm{DC}$ & 1 & 31.3 & 29.7 & 25.0 \\
\hline
\end{tabular}

\section{Discussion}

The combined experimental and computational mechanistic investigations point toward a rationalization based on DC group transfer and involving a $\mathrm{Cu}^{\mathrm{II}} / \mathrm{Cu}^{\mathrm{III}}$ redox pair for the controlled polymerization of styrene and MMA by the $\left[\mathrm{Cu}(\mathrm{acac})_{2}\right]$ or $\left[\mathrm{Cu}(\mathrm{hfa})_{2}\right] / \mathrm{MAN}-\mathrm{DC}$ system, in the absence of external radical sources or reducing agents. This is made possible by the lower energy involved for the DC group transfer from the dithiocarbamate initiator and from the end of the growing chain to the $\mathrm{Cu}^{\mathrm{II}}$, relative to a $\mathrm{Br}$ atom transfer in ATRP.

The fact that the proposed $\left[\mathrm{Cu}^{\mathrm{III}}(\mathrm{acac})_{2}(\mathrm{DC})\right]$ and $\left[\mathrm{Cu}^{\mathrm{III}}(\mathrm{hfa})_{2}(\mathrm{DC})\right]$ are thermodynamically unstable relative to the corresponding $\mathrm{Cu}^{\mathrm{II}}$ and DC-DC does not preclude the in situ generation of such species by group transfer and their function as spin traps. The reason for this is that the energy required to accomplish the group transfer is kinetically compatible with the polymerization rate. Once the $\mathrm{Cu}^{\mathrm{III}}$ complex is formed together with the active radical chain, it has the choice of either deactivating the radical or decompose by reduction and formation of DCDC. However, whereas the former process is first order in $\mathrm{Cu}^{\mathrm{III}}$ (and first order in radical), the 
latter one is second order in $\mathrm{Cu}^{\mathrm{III}}$ and will consequently be disfavoured at low concentrations. This is the same principle governing the preferred spin trapping of the reactive radical chain relative to the bimolecular radical-radical couplings and disproportionations. This principle, according to which the spin trapping species in controlled radical polymerization need not be a stable species, is not unprecedented. The same phenomenon was previously demonstrated for the ATRP of styrene with control by $\left[\mathrm{Mo}^{\mathrm{III}} \mathrm{I}_{3}\left(\mathrm{PMe}_{3}\right)_{3}\right]$, where the proposed $\left[\mathrm{Mo}^{\mathrm{IV}} \mathrm{I}_{3} \mathrm{Br}\left(\mathrm{PMe}_{3}\right)_{3}\right]$ product of atom transfer was shown to be a thermodynamically unstable species with respect to $\left[\mathrm{Mo}^{\mathrm{III}} \mathrm{I}_{2} \mathrm{Br}\left(\mathrm{PMe}_{3}\right)_{3}\right]$ and $\mathrm{I}_{2}{ }^{36}$.

CONCLUSIONS. Well-controlled radical polymerization of MMA and styrene were conducted with halogen-free alkyl dithiocarbamate initiators (MAN-DC, EMA-DC) and oxidatively stable copper(II) acetylacetonate derivatives. PMMA and PSt with narrow MWD were obtained $\left(M_{\mathrm{w}} / M_{\mathrm{n}}<1.1\right.$ for PMMA and $M_{\mathrm{w}} / M_{\mathrm{n}}<1.2$ for PSt). It was found that the polymerization system containing $\left[\mathrm{Cu}(\mathrm{hfa})_{2}\right]$ provided better control than that with $\left[\mathrm{Cu}(\mathrm{acac})_{2}\right]$. Chain extension of a PMMA macroinitiator prepared with the $\left[\mathrm{Cu}(\mathrm{hfa})_{2}\right]$ catalyst with MMA exhibited high initiation efficiency (96\%) and formed a higher MW polymer with a narrow MWD, $M_{\mathrm{w}} / M_{\mathrm{n}} \sim 1.2$. Mechanistic studies indicate that the polymerization proceeds via a reversible DC group transfer process generating $\mathrm{Cu}^{\mathrm{III}}$-DC species, which are competent radical chain deactivators in spite of their thermodynamic instability. This constitutes the first reported example of a controlled radical polymerization involving the $\mathrm{Cu}$ II $/ \mathrm{Cu}^{\mathrm{III}}$ redox pair.

\section{AUTHOR INFORMATION}

\section{Corresponding Author}


*E-mail:km3b@andrew.cmu.edu.

Present Addresses

$†$ Silberline Manufacturing Co., Inc., 36 Progressive Avenue, Tamaqua, PA, 18252.

\section{Author Contributions}

All authors have given approval to the final version of the manuscript.

\section{ACKNOWLEDGMENT}

Financial support from the National Science Foundation (CHE 10-26060) is gratefully acknowledged. K.S. thanks the Deutsche Forschungsgemeinschaft (DFG) for her postdoctoral fellowship (SCHR 1314/1-2). The Toulouse group acknowledges the Agence National de la Recherche (ANR-2010-BLANC-7101), the Centre National de la Recherche Scientifique (CNRS) and the Institut Universitaire de France (IUF) for funding. This work was granted access to the HPC resources of CINES under the allocation 2013-086343 made by GENCI (Grand Equipement National de Calcul Intensif) and to the resources of the CICT (Centre Interuniversitaire de Calcul de Toulouse, project CALMIP).

\section{ASSOCIATED CONTENT}

Supporting Information. Detailed experimental protocols for polymerization, characterization, iniferter synthesis and additional results are available free of charge via the Internet at http://pubs.acs.org.

\section{REFERENCES}


1. (a) Matyjaszewski, K.; Davis, T. Handbook of Radical Polymerization; Wiley-Interscience, 2002; (b) Braunecker, W. A.; Matyjaszewski, K. Progress in Polymer Science 2007, 32, 93-146. 2. (a) Hawker, C. J.; Bosman, A. W.; Harth, E. Chemical Reviews 2001, 101, 3661-3688; (b) Georges, M. K.; Veregin, R. P. N.; Kazmaier, P. M.; Hamer, G. K. Macromolecules 1993, 26, 2987-2988; (c) Benoit, D.; Grimaldi, S.; Robin, S.; Finet, J.-P.; Tordo, P.; Gnanou, Y. Journal of the American Chemical Society 2000, 122, 5929-5939; (d) Nicolas, J.; Guillaneuf, Y.; Lefay, C.; Bertin, D.; Gigmes, D.; Charleux, B. Progress in Polymer Science 2013, 38, 63-235.

3. (a) Matyjaszewski, K.; Xia, J. H. Chemical Reviews 2001, 101, 2921-2990; (b) Kamigaito, M.; Ando, T.; Sawamoto, M. Chemical Reviews 2001, 101, 3689-3745; (c) Kato, M.; Kamigaito, M.; Sawamoto, M.; Higashimura, T. Macromolecules 1995, 28, 1721-1723; (d) Wang, J. S.; Matyjaszewski, K. Journal of the American Chemical Society 1995, 117, 5614-5615; (e) Matyjaszewski, K. Macromolecules (Washington, DC, United States) 2012, 45, 4015-4039. 4. (a) Perrier, S.; Takolpuckdee, P. Journal of Polymer Science Part a-Polymer Chemistry 2005, 43, 5347-5393; (b) Chiefari, J.; Chong, Y. K.; Ercole, F.; Krstina, J.; Jeffery, J.; Le, T. P. T.; Mayadunne, R. T. A.; Meijs, G. F.; Moad, C. L.; Moad, G.; Rizzardo, E.; Thang, S. H. Macromolecules 1998, 31, 5559-5562; (c) Moad, G.; Rizzardo, E.; Thang, S. H. Australian Journal of Chemistry 2005, 58, 379-410; (d) Matyjaszewski, K.; Gaynor, S.; Wang, J.-S. Macromolecules 1995, 28, 2093-2095; (e) Greszta, D.; Mardare, D.; Matyjaszewski, K. Macromolecules 1994, 27, 638-644; (f) Matyjaszewski, K.; Gaynor, S.; Greszta, D.; Mardare, D.; Shigemoto, T. Journal of Physical Organic Chemistry 1995, 8, 306-315; (g) Gregory, A.; Stenzel, M. H. Progress in Polymer Science 2012, 37, 38-105; (h) Beija, M.; Marty, J.-D.; Destarac, M. Progress in Polymer Science 2011, 36, 845-886.

5. (a) Davis, K. A.; Matyjaszewski, K. Advances in Polymer Science 2002, 159, 1-166; (b) Gao, H.; Matyjaszewski, K. Progress in Polymer Science 2009, 34, 317-350; (c) Lee, H.-i.; Pietrasik, J.; Sheiko, S. S.; Matyjaszewski, K. Progress in Polymer Science 2010, 35, 24-44; (d) Sheiko, S. S.; Sumerlin, B. S.; Matyjaszewski, K. Progress in Polymer Science 2008, 33, 759-785; (e) Siegwart, D. J.; Oh, J. K.; Matyjaszewski, K. Progress in Polymer Science 2012, 37, 18-37; (f) Coessens, V.; Pintauer, T.; Matyjaszewski, K. Progress in Polymer Science 2001, 26, 337-377; (g) Matyjaszewski, K. Progress in Polymer Science 2005, 30, 858-875; (h) Olivier, A.; Meyer, F.; Raquez, J.-M.; Damman, P.; Dubois, P. Progress in Polymer Science 2012, 37, 157-181; (i) Mecerreyes, D. Progress in Polymer Science 2011, 36, 1629-1648; (j) Rikkou, M. D.; Patrickios, 
C. S. Progress in Polymer Science 2011, 36, 1079-1097; (k) Matyjaszewski, K.; Tsarevsky, N. V. Nature Chemistry 2009, 1, 276-288; (1) Tasdelen, M. A.; Kahveci, M. U.; Yagci, Y. Progress in Polymer Science 2011, 36, 455-567.

6. (a) Otsu, T.; Yoshida, M.; Tazaki, T. Makromolekulare Chemie-Rapid Communications 1982, 3, 133-140; (b) Otsu, T. Journal of Polymer Science Part A: Polymer Chemistry 2000, 38, 21212136.

7. (a) Poli, R. European Journal of Inorganic Chemistry 2011, 1513-1530; (b) Debuigne, A.; Poli, R.; Jérôme, C.; Jérôme, R.; Detrembleur, C. Progress in Polymer Science 2009, 34, 211 239; (c) Wayland, B. B.; Poszmik, G.; Mukerjee, S. L.; Fryd, M. Journal of the American Chemical Society 1994, 116, 7943-7944; (d) Debuigne, A.; Caille, J.-R.; Detrembleur, C.; Jérôme, R. Angewandte Chemie International Edition 2005, 44, 3439-3442; (e) Debuigne, A.; Caille, J.-R.; Jérôme, R. Angewandte Chemie International Edition 2005, 44, 1101-1104; (f) Maria, B.; Kaneyoshi, H.; Matyjaszewski, K.; Poli, R. Chemistry-a European Journal 2007, 13, 2480-2492; (g) Allan, L. E. N.; Perry, M. R.; Shaver, M. P. Progress in Polymer Science 2012, $37,127-156$.

8. (a) Ouchi, M.; Terashima, T.; Sawamoto, M. Chemical Reviews 2009, 109, 4963-5050; (b) Singha, N. K.; Klumperman, B. Macromolecular Rapid Communications 2000, 21, 1116-1120; (c) Davis, K. A.; Matyjaszewski, K. Journal of Macromolecular Science, Part A 2004, 41, 449465; (d) Sarbu, T.; Matyjaszewski, K. Macromolecular Chemistry and Physics 2001, 202, 33793391; (e) di Lena, F.; Matyjaszewski, K. Progress in Polymer Science 2010, 35, 959-1021.

9. Fischer, H. Journal of Polymer Science Part A: Polymer Chemistry 1999, 37, 1885-1901.

10. (a) Jakubowski, W.; Matyjaszewski, K. Angewandte Chemie International Edition 2006, 45, 4482-4486; (b) Tsarevsky, N. V.; Matyjaszewski, K. Chemical Reviews 2007, 107, 2270-2299. 11. Matyjaszewski, K.; Jakubowski, W.; Min, K.; Tang, W.; Huang, J.; Braunecker, W. A.; Tsarevsky, N. V. Proceedings of the National Academy of Sciences 2006, 103, 15309-15314.

12. Magenau, A. J. D.; Strandwitz, N. C.; Gennaro, A.; Matyjaszewski, K. Science 2011, 332, 81-84.

13. Konkolewicz, D.; Schröder, K.; Buback, J.; Bernhard, S.; Matyjaszewski, K. ACS Macro Letters 2012, 1, 1219-1223.

14. (a) Kwak, Y.; Yamamura, Y.; Matyjaszewski, K. Macromolecular Chemistry and Physics 2010, 211, 493-500; (b) Kwak, Y.; Nicolaÿ, R.; Matyjaszewski, K. Macromolecules 2008, 41, 
6602-6604; (c) Nicolaÿ, R.; Kwak, Y.; Matyjaszewski, K. Angewandte Chemie International Edition 2010, 49, 541-544; (d) Kwak, Y.; Nicolay, R.; Matyjaszewski, K. Macromolecules 2009, 42, 3738-3742; (e) Nicolay, R.; Kwak, Y.; Matyjaszewski, K. Macromolecules 2008, 41, 45854596.

15. (a) Kwak, Y.; Matyjaszewski, K. Macromolecules 2010, 43, 5180-5183; (b) Kwak, Y.; Matyjaszewski, K. Macromolecules 2008, 41, 6627-6635.

16. (a) Aoki, S.; Matsumur.S; Otsu, T. Bulletin of the Chemical Society of Japan 1969, 42, 25742577; (b) Bamford, C. H.; Lind, D. J. Proceedings of the Royal Society of London Series A 1968, $302,145-165$.

17. Schellenberg, J.; Geike, R.; Opitz, G.; Ulbricht, J. Plaste und Kautschuk 1982, 29, 497-\&.

18. Kaeriyam.K Makromolekulare Chemie 1971, 150, 189-197.

19. Uehara, K.; Tanaka, M.; Murata, N. Kogyo Kagaku Zasshi 1967, 70, 1564-1567.

20. Chen, J.; Ma, S. Chemistry-an Asian Journal 2010, 5, 2415-2421.

21. Salomon, R. G.; Kochi, J. K. Journal of the American Chemical Society 1973, 95, 33003310 .

22. (a) Dong, H.; Matyjaszewski, K. Macromolecules 2008, 41, 6868-6870; (b) Matyjaszewski, K.; Dong, H.; Jakubowski, W.; Pietrasik, J.; Kusumo, A. Langmuir 2007, 23, 4528-4531.

23. (a) Nasibulin, A. G.; Kauppinen, E. I.; Brown, D. P.; Jokiniemi, J. K. The Journal of Physical Chemistry B 2001, 105, 11067-11075; (b) Nasibulin, A. G.; Shurygina, L. I.; Kauppinen, E. I. Colloid Journal 2005, 67, 1-20.

24. Bett, S. J.; Fletcher, G.; Garnett, J. L. International Journal of Radiation Applications and Instrumentation. Part C. Radiation Physics and Chemistry 1986, 28, 207-210.

25. Naumann, D.; Roy, T.; Caeners, B.; Hutten, D.; Tebbe, K. F.; Gilles, T. Zeitschrift Fur Anorganische Und Allgemeine Chemie 2000, 626, 999-1003.

26. (a) Victoriano, L.; Granifo, J.; Parraguez, L. Boletin De La Sociedad Chilena De Quimica 2000, 45, 487-490; (b) Victoriano, L. I. Polyhedron 2000, 19, 2269-2275.

27. (a) Hogarth, G.; Pateman, A.; Redmond, S. P. Inorganica Chimica Acta 2000, 306, 232-236;

(b) Hogarth, G.; Rainford-Brent, E.-J. C. R. C. R.; Richards, I. Inorganica Chimica Acta 2009, $362,1361-1364$.

28. Yusuff, K. K. M.; Mathew, E. J. Journal of Coordination Chemistry 1992, 26, 133-135.

29. Coote, M. L.; Davis, T. P. Progress in Polymer Science 1999, 24, 1217-1251. 
30. Lin, C. Y.; Coote, M. L.; Petit, A.; Richard, P.; Poli, R.; Matyjaszewski, K. Macromolecules 2007, 40, 5985-5994.

31. Gillies, M. B.; Matyjaszewski, K.; Norrby, P.-O.; Pintauer, T.; Poli, R.; Richard, P.

Macromolecules 2003, 36, 8551-8559.

32. (a) Maverick, A. W.; Fronczek, F. R.; Maverick, E. F.; Billodeaux, D. R.; Cygan, Z. T.;

Isovitsch, R. A. Inorganic Chemistry 2002, 41, 6488-6492; (b) Starikova, Z. A.; Shugam, E. A.

Zh. Strukt. Khim. (Russ.) (J. Struct. Chem.) 1969, 10, 290.

33. Santo, R.; Miyamoto, R.; Tanaka, R.; Nishioka, T.; Sato, K.; Toyota, K.; Obata, M.; Yano, S.; Kinoshita, I.; Ichimura, A.; Takui, T. Angewandte Chemie-International Edition 2006, 45, 7611-7614.

34. Wells, A. F. Structural Inorganic Chemistry; Clarendon Press: Oxford, 1984.

35. Bertrand, J. A.; Kaplan, R. I. Inorganic Chemistry 1966, 5, 489-491.

36. Maria, S.; Stoffelbach, F.; Mata, J.; Daran, J.-C.; Richard, P.; Poli, R. J. Am. Chem. Soc. 2005, 127, 5946-5956. 
For Table of Contents Use Only

\section{Reversible-Deactivation Radical Polymerization of Methyl}

Methacrylate and Styrene Mediated by Alkyl Dithiocarbamate

\section{and Copper Acetylacetonates}

Yaozhong Zhang, Kristin Schröder, Yungwan Kwak,,$^{\dagger}$ Pawel Krys, Aurélie N. Morin, ${ }^{\star}$ Tomislav Pintauer ${ }^{\not+ \pm}$ Rinaldo Poli,,${ }^{+}$and Krzysztof Matyjaszewski*

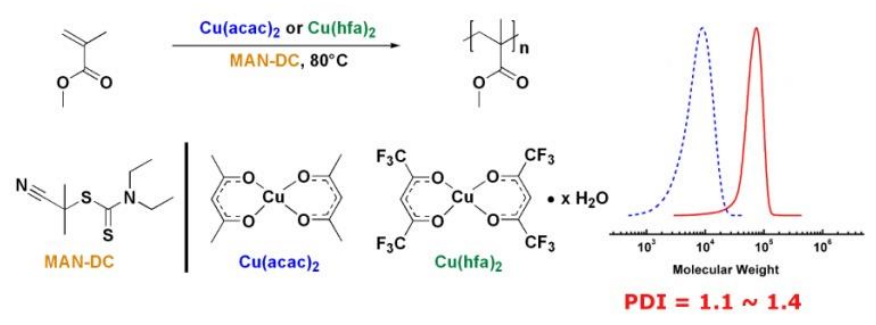

